\title{
MEMOIR
}

\section{SIDNEY BENJAMIN}

WE are all familiar with the words of Bacon which appear on the front of every issue of this Journal. Sidney used them in the speech he made in October 1985 when receiving his Gold Medal from the Institute, ". . . every man is a debtor to his profession", he said, ". . . and that debt becomes urgent when the profession is very small in number."

If ever that statement applied in reverse and his profession was the debtor of a man, then ours is the profession and Sidney Benjamin is that man. His contribution to the widening of our horizons is unparalleled.

It is part of actuarial lore that his first paper to the Institute of Actuaries (written jointly with Charles Bennett) on 'The Application of Linear Programming to Approximate Valuation' was presented on the same day that he received his Fellowship certificate. He subsequently explored every area of actuarial activity and opened up many new ones. His mind was lucid, penetrating and unremittingly inquisitive.

After Cambridge, Sidney joined the Prudential where he thrived under the wings of Frank Redington, who encouraged him to produce research work, and Kenneth Usherwood, who sent him back to Cambridge to learn computer programming. This led to the Students' Society programming course which Sidney ran through its first decade. The generation of actuaries who became computer literate in the 1960s and 1970s were inspired and trained by Sidney or by people whom Sidney had inspired or trained.

In order to develop his knowledge of computing, which he recognised as being of fundamental importance to the profession, he moved to Ferranti Computers where he worked on the Cambridge University Atlas project. In 1962 he joined the consulting actuaries Bacon \& Woodrow and, having become a partner in the following year, he spent the remainder of his working life with the firm. His most immediate mission was to build the firm's computer appreciation and skills, and his 1966 Institute paper 'Putting Computers onto Actuarial Work' followed.

Consulting life was his natural home. It made full use of his skills as an extraordinarily able problem-solver, helped by a penetrating intellcet, a widc-ranging stock of technical and practical knowledge, and a host of professional and academic friends. Once he had decided what needed to be done, he was an eloquent and patient explainer of complex ideas.

His son-in-law tells of admitting that he had never really understood the basis of logarithms at which 'Sidney's eyes lit up' and the result was twenty lucid and amusing pages on the subject. Whocan forget the occasions when Sidney's eyes lit up?

He wrote papers on investment, computing, life insurance, general insurance, pensions and healthcare. In an era of increasing specialisation and narrowing focus, he was our Leonardo $\mathrm{Da}$ Vinci. Most of his papers were seminal, all were enjoyable, adventurous and challenging. Some of them were presented to the Institute, others to congresses, overseas societies and other learned bodies. The Journal records his contribution to well over 50 of our discussions--invariably pertinent, succinct and good-humoured.

It comes as no surprise to find, on the first page of the last paper discussed at the Institute prior to his death, "The origin of the Working Party was a remark by Professor $\mathbf{S}$. Benjamin in the discussion at the Institute . . $\therefore$ It is daunting to reflect on how many research projects, papers, articles and studies originated in a remark or question of Sidney's.

Many of those who have carried out original research were fired by Sidney's energy, enthusiasm for new ideas and encouragement. This drive was channelled through his Chairmanship of the Research Committee for over 20 years. All of us who have enjoyed reading the products of that research, or who have profited from it, are indebted to him.

All those who work in unit-linked insurance would probably not be doing so if he had not laid the 
foundations of policy design and reserving. The actuaries who still struggle to demonstrate how we can help in the world of general insurance would have made much less progress if it had not been for his pionecring work for general insurance companies and the Lloyds market.

He was an ardent advocate of the concepts of professionalism which he served on the Council of the Institute from 1962 to 1985 . He was a Vice-President from 1975 to 1978 . He was a member of the Society of Actuaries Research Committee, a fellow of the British Computer Society and also of the Royal Statistical Society-where he served a term on their Council and as Chairman of their General Applications Committee. In 1985, he was appointed a Visiting Professor at City University.

Sidney and his work were known by actuaries throughout the world. He and his wife Goldie welcomed them into their home and visited and corresponded with them everywhere else.

Somehow in parallel with his enomous professional output, Sidney found time for his private loves of sketching and painting (in water colours and oils---quite expertly and often on painting holidays with his son), music and chess.

His last formal presentation at the Institute was on the subject of 'Actuarial Funding of Long-term Care for the Elderly'. His interest had been directed to this topic by the increasing infirmity of his father, who had retained his health and independence into his nineties. It is particularly ironic that Sidney was survived by his father as well as by Goldie and his son Ivor and daughter Sara.

Those who loved his humour, kindness and generosity throughout his life were filled with admiration by the courage with which, for more than a year, he and Goldie resisted the cancer which killed him. If bravery were sufficient to achieve a cure, he would be with us today.

Sidney Benjamin was born on 6 June 1928, educated at Bancrofts School and Corpus Christi College, Cambridge, and died on 18 February 1992. All who knew him were privileged.

COLIN D. LEVER 